
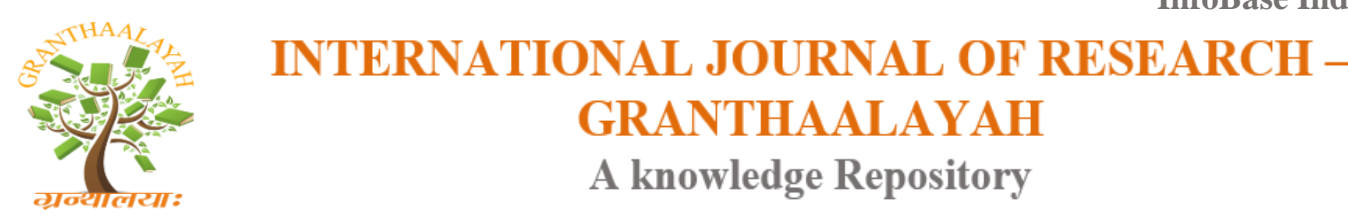

\title{
Social
}

\section{IMPACT OF SOCIAL MEDIA ON SCHOLASTIC ACHIEVEMNT}

\author{
G.Sheela $^{* 1}$, Mrs. T. Sangeetha ${ }^{2}$ \\ ${ }^{*}$ MEd Scholar, RVS College of Education, India \\ ${ }^{2}$ Assistant Professor in Commerce Education, RVS College of Education, India
}

DOI: https://doi.org/10.29121/granthaalayah.v5.i3(SE).2017.1939

\begin{abstract}
Social media has transformed and impacted on communication, learning, research and education in general. The study aimed to examine the impact of social media on scholastic achievement among higher secondary students The investigator adopted survey method to study the impact of social media on scholastic achievement among higher secondary students. For this study a sample of 300 higher secondary students from five Govt and Private schools which are situated in and around Udumalpet town of Tirupur district in Tamil Nadu were selected by the investigator using simple random sampling technique. The findings reveal that there is no significant impact of social media on scholastic achievement among selected higher secondary students.
\end{abstract}

Keywords: Social Media; Scholastic Achievements; Education.

Cite This Article: G.Sheela, and Mrs. T. Sangeetha. (2017). "IMPACT OF SOCIAL MEDIA ON SCHOLASTIC ACHIEVEMNT." International Journal of Research Granthaalayah, 5(3)SE, 47-50. https://doi.org/10.29121/granthaalayah.v5.i3(SE).2017.1939.

\section{Introduction}

The Internet revolution changed the information world with regard to sharing, speed, storage and retrieval of information in whatever form regardless of the person's location. Through the Internet a number of web technologies emerged, and one technology that is making waves with regard to information sharing and communication are the social media networks. The evolution of social media has cut across all facets of society with its positive and negative impacts. Social media has transformed and impacted on communication, learning, research and education in general. Among the vast variety of online tools which are available for communication, social networking sites (SNS) have become the most modern and attractive tools for connecting people throughout the world (Aghazamani, 2010).

Davis et al (2012), refer to social media technology (SMT) as "web-based and mobile applications that allow individuals and organizations to create, engage, and share new user- 
generated or existing content, in digital environments through multi-way communication". Through this platform, individuals and organizations create profiles, share and exchange information on various activities and interests. An interesting aspect of social media is that, it is not limited to desktop or laptop computers but could be accessed through mobile applications and smart phones making it very accessible and easy to use. Examples of these social media platforms both on the web and mobile application include Facebook, Twitter, YouTube, Whatsapp, Instagram, blogs etc.

A number of research studies have been done on social media. According to Boyd \& Ellison (2007), "Social networking sites are web-based services that allow individuals to construct a public or semi-public profile within a bounded system, articulate a list of other users with whom they share a connection, and view and traverse their list of connections and those made by others within the system". These sites are used to interact with friends, peers and others that are found in groups on these sites. The sharing of information ranges from news, debates, gossips, feelings or statement of mind, opinions, research etc. A number of studies have been conducted to find out the impact of social media on academic performance of students. According to Ito et al. (2009), teens use these technologies for a number of positive activities, which include delving deeper into interest-driven communities and participating in various activities. Ahn (2011) adds that "Social Network Sites (SNS) provide a platform for the youth to participate in communities that help them to learn, and practice skills within a particular knowledge area". Similarly, a study by Fishman et al (2005), also indicated that college students produce tremendous volume of writing through various social media tools such as blogs, emails and other social media environments.

\section{Research Design}

The investigator adopted survey method to study the impact of social media on scholastic achievement among higher secondary students.. For this study a sample of 300 higher secondary students from five Govt and Private schools which are situated in and around Udumalpet town of Tirupur district in Tamil Nadu were selected by the investigator using simple random sampling technique.

\section{Hypothesis 1:}

There will be a difference in the level of usage of social media among higher secondary students.

Table 1: Frequency and percentage difference in the level of usage social media among higher secondary students

\begin{tabular}{|c|c|c|c|c|c|c|c|c|}
\hline \multicolumn{9}{c|}{ SOCIAL MEDIA } \\
\hline \multicolumn{3}{|c|}{ Low } & \multicolumn{3}{c|}{ Moderate } & \multicolumn{3}{c|}{ High } \\
\hline Q1 & F & \% & Q2 & F & \% & Q3 & F & \% \\
\hline 101 & 79 & $26.33 \%$ & 108 & 158 & $52.66 \%$ & 115 & 63 & $21 \%$ \\
\hline
\end{tabular}

Table 1 exhibits the result in the level of usage of social media among higher secondary students. According to the table totally $26.33 \%$ of higher secondary student belong to low social media usage, $56.66 \%$ of higher secondary students belong to moderate level of usage of social media, and $21 \%$ of higher secondary students belong to high level of usage of social media. 


\section{Hypothesis 2:}

There will be a difference in the level of scholastic achievements among higher secondary students.

Table 2: Frequency and percentage difference in the level of scholastic achievement among higher secondary students

\begin{tabular}{|c|c|c|c|c|c|c|c|c|}
\hline \multicolumn{1}{|c|}{ SCHOLASTIC ACHIEVEMENT } \\
\hline \multicolumn{3}{|c|}{ Low } & \multicolumn{3}{c|}{ Moderate } & \multicolumn{3}{c|}{ High } \\
\hline Q1 & F & \% & Q2 & F & \% & Q3 & F & \% \\
\hline 883 & 75 & 25 & 966 & 151 & 50.33 & 1067 & 74 & 24.66 \\
\hline
\end{tabular}

Table 2 exhibits the result of the difference in the level of scholastic achievements among higher secondary students. According to the table totally $25 \%$ of higher secondary students belong to low level in scholastic achievement, $50.33 \%$ of higher secondary students belong to moderate level in the scholastic achievement, and $24.66 \%$ of higher secondary students belong to high level in the scholastic achievement.

\section{Hypothesis 3:}

There will be a significant difference in the impact of social media and their effect on scholastic achievement among selected higher secondary students.

Table 3: Model Summary

\begin{tabular}{|l|c|c|l|l|}
\hline Model & R & R Square & $\begin{array}{c}\text { Adjusted R } \\
\text { Square }\end{array}$ & $\begin{array}{c}\text { Std. Error of } \\
\text { Estimate }\end{array}$ \\
\hline 1 & $.168^{\mathrm{a}}$ & .028 & .008 & 132.859 \\
\hline
\end{tabular}

Predictor: Social media usage

Dependent Variable: Scholastic achievement

From the above table, $\mathrm{R}$ indicates the correlation between the observed and the predicted value of the dependent variable scholastic achievement which is 0.168 . R Square indicates the proportion of the variance in the dependent variable namely scholastic achievement that is explained by the effect of the independent variable namely impact of social media.

Histogram

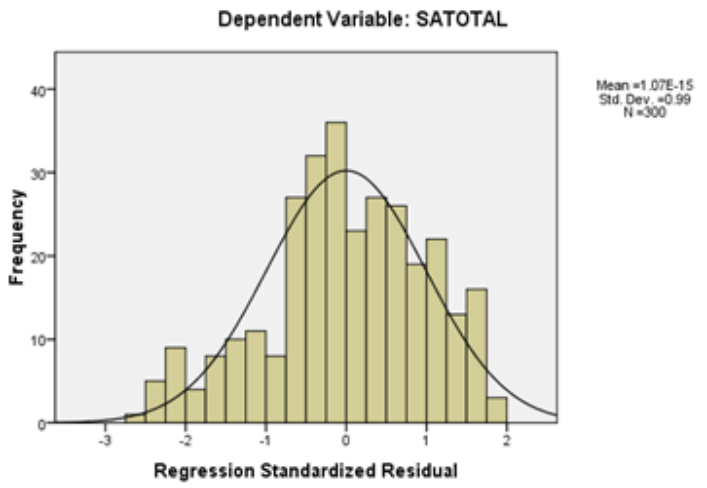

The above histogram shows that the distribution is normal, which is a basic requirement for regression analysis. 
Table 4: ANNOVA

\begin{tabular}{|ll|l|l|l|l|c|}
\hline \multicolumn{1}{|c|}{ Model } & Sum of Squares & df & Mean Square & \multicolumn{1}{c|}{ F } & Sig. \\
\hline 1 & Regression & 150427.420 & 6 & 25071.237 & 1.420 & $.206^{\mathrm{a}}$ \\
& Residual & 5171862.376 & 293 & 17651.407 & & \\
& Total & 5322289.797 & 299 & & & \\
\hline
\end{tabular}

In the above table, the sum of squares associated with the three variance regression, residuals and the total. The total variance is partitioned into regression (150427.420) and residuals (5171862.376) which indicate the variance explained by the independent variable and the variance not explained by the independent variable.

The $\mathrm{F}$ value is statistically not significant at 0.05 level, it suggest that no linear relationship among the variables. Hence, the hypothesis 3 is rejected and it is concluded that there is no significant impact of social media on scholastic achievement among selected higher secondary students.

\section{Conclusion}

The findings reveal that totally $25 \%$ of higher secondary students belong to low level in scholastic achievement, $50.33 \%$ of higher secondary students belong to moderate level in the scholastic achievement, and $24.66 \%$ of higher secondary students belong to high level in the scholastic achievement. Also it is found that there is no significant impact of social media on scholastic achievement among selected higher secondary students.

\section{References}

[1] Ahmed, I. and Qazi T. F. (2011). A Look Out for Academic Impacts of Social Networking Sites: A Student Based Perspective. African Journal of Business Management, 5(12), 5022-5031. doi:10.5897/AJBM11.595

[2] Ahn, J. (2011). The Effect of Social Network Sites on Adolescents' Social and Academic Development: Current Theories and Controversies., . Journal of the American Society for Information Science and Technology, 8(62), 1435-1445. doi:DOI: 10.1002/asi.21540

[3] Ainin, S., Naqshbandi, N. M., Moghavvemi, S., Jaafar, N. I. (2015). Facebook Usage, Socialization and Academic Performance. Computers \& Education 83 (2015) 64-73. http://dx.doi.org/10.1016/j.compedu.2014.12.018

[4] Golden, S. A. R. (2016). RURAL STUDENTS'ATTITUDE TOWARDS ENGLISH AS MEDIUM OF INSTRUCTION IN HIGHER EDUCATION-AN ANALYSIS. International Journal of Research, 3, 1-10.

[5] Golden, S. A. R. (2017). Attitude of Students and Teachers towards E- Learning - An Analysis. Recent Research in Social Science \& Humanities, 1, 5-10.

[6] Jeffrey Mingle (2016)- Social Media Network Participation and Academic Performance In Senior High Schools in Ghana Lancaster University Ghana, minglej2000@yahoo.com

[7] Malaney, G. D. (2005). Student Use of the Internet. Journal of Educational Technology Systems, 33(1), 53-66

[8] Rithika, M. and Selvaraj, S. (2013). Impact of Social Media on Students' Academic Performance. International Journal of Logistics and Supply Chain Management Perspective, 2(4), 636-640. 